\title{
ANALISIS ASPEK RASIONAL DALAM PENGANGGARAN PUBLIK TERHADAP EFEKTIVITAS PENGIMPLEMENTASIAN ANGGARAN BERBASIS KINERJA PADA PEMERINTAH KOTA SURAKARTA
}

\author{
Oleh : Fatchan Achyani, SE, M.Si \\ (Universitas Muhammadiyah Surakarta) \\ Bayu Tri Cahya,SE,M.Si \\ (Sekolah Tinggi Agama Islam Negeri Kudus)
}

\begin{abstract}
Penelitian ini bertujuan untuk mengetahui pengaruh aspek rasional yaitu sumber daya, informasi, dan orientasi tujuan terhadap implementasi efektivitas anggaran berbasis kinerja. Penerapan anggaran berbasis kinerja dimaksudkan agar dalam perencanaan, pelaksanaan, dan pertanggungjawaban anggaran, setiap institusi publik tidak hanya mempertanggungjawabkan input-nya semata tetapi juga harus mempertanggungjawabkan untuk apa dan berapa output dan hasil (outcome) yang diperoleh dari setiap dana yang dibelanjakan. Dari analisis regresi yang dilakukan dapat disimpulkan bahwa variabel sumber daya dan informasi, terbukti mempengaruhi secara positif efektivitas implementasi anggaran berbasis kinerja pada pemerintah kota Surakarta.
\end{abstract}

Kata kunci : Efektivitas Implementasi Anggaran Berbasis Kinerja, Sumber Daya, Informasi, Orientasi Tujuan 


\section{PENDAHULUAN}

Perkembangan reformasi sektor publik yang begitu dinamis saat ini idal dapar dilepaskan dari tuntutan masyarakat yang woihat secara kritis buruknya kinerja pemerintah dalam mengclola sumber daya publik. Perubahan suatu sistem politik, sosial, dan kemasyarakatan serta ekonomi yang dibawa oleh arus reformasi telah menimbulkan tuntutan yang beragam terhadap pengelolaan pemerintahan yang baik (Asmadewa, 2006). Agenda-agenda reformasi terhadap tuntutan perubahan organisasional kemudian menciptakar sejumlah prinsip atau doktrin tata kelola pemeintahan seperti cerangkum dalam konsep new public management (Hood,1991), atau prinsip reinventing goverment (Osborne dan Gaebler, 1993). Seperti yang telah dilakukan di Amerika Serikat pada awal mula mengimplementasikan anggaran berbasis kinerja yaitu dengan dibentuknya Komisi Hoover pada tahun 1949 untuk mendukung konsep anggaran berbasis kinerja hingga diberlakukannya GPRA (Government Performance and Result Act) tahun 1993. GAO (General Accounting Office) tahun 1993 juga menjelaskan bahwa reformasi anggaran telah berusaha merubah penekanan anggaran dari pengendalian belanja line item kepada alokasi sumber daya berdasarkan tujuan program dan ukuran-ukuran hasil.

Anggaran berbasis kinerja di Indonesia telah diperkenalkan dalam Undang-Undang No. 17 tahun 2003 tentang Keuangan Negara yang menjelaskan bahwa rencana kerja dan anggaran disusun berdasarkan prestasi kerja yang akan dicapai atau berbasis kinerja. Penjelasan UndangUndang tersebut menguraikan bahwa anggaran berbasis prestasi kerja merupakan upaya untuk memperbaiki proses penganggaran di sektor publik. Dengan disahkannya Permendagri No. 13 tahun 2006 tentang pedoman pengelolaan keuangan daerah (Bastian, 2006). Sesuai der gan Permendagri No. 13 tahun 2006 penganggaran yang baik akan memberikan dasar bagi pengukuran kinerja dan menghasilkan informasi kinerja yaing valid dan akurat, sehingga dapat digunakan sebagai bahan penyusunan laporan kinerja untuk pengendalian.

Dilihat dari sudut pandang rasional, implementasi anggaran berbasis kinerja merupakan isu teknis. Sistem pengukuran kinerja yang dilandasi oleh konsep value for money, dan anggaran yang berorientasi hasil yang menekankan pemikiran logis dan rasional dalam mengelola suatu perubahan dalam suatu organisasi. Organisasi kemudian dapat dimodifikasi dengan mengaplikasikan perencanaan rasional secara ilmiah untuk mencapai efektivitas dan efisiensi keseluruhan organisasi (Julnez dan Holzer, 2001). Dengan mempertimbangkan kelemahan dan kelebihan anggaran berbasis kinerja dan perkembangan penelitian terdahulu yang masih beragam, maka evaluasi atas status implementasi anggaran berbasis kinerja yang telah dicapai pemerintah daerah saat in ocoting untuk diteliti. Hal ini untuk mengetahui apakaĭ perubahan pendekatan anggaran ini efektif dijalankan atau hanya menjadi aksi simbolis yang terjebak pada formalitas penyusunan anggaran dan pada akhirnya berujung pada kegagalan reformasi. Hal ini merupakan upaya untuk menjaga momentum perubahan ini agar selalu pada jalur yang tepat (Bastian, 2006). Karenanya, penelitian ini akan meneliti status perkembangan atau efektivitas implementasi anggaran berbasis kinerja pemerintah daerah terkait aspek rasional yang mempengaruhinya dari perspektif teori organisasi yang melihat perubahan dalam pendekatan anggaran sebagai perubahan organisasional.

Penelitian ini akan menanyakan persepsi para pejabat (penganggar) pada lembaga/instansi di lingkup pemerintah kota Surakarta tentang pengaruh aspek rasional (sumber daya, informasi, dan orientasi tujuan) terhadap efektivitas implementasi anggaran berbasis kinerja. Hal inilah yang merupakan perluasan penelitian yang membedakan dengan penelitian-penelitian sebelumnya.

\section{LANDASAN TEORI}

\section{Anggaran Berbasis Kinerja}

Konsep performance budgeting (penganggaran kinerja) dalam sejarahnya diperkenalkan pertama kali di AS pada tahun 1949 oleh Komisi Hoover dimana reformasi anggaran telah berusaha merubah penekanan anggaran dari pengendalian belanja line item kepada alokasi sumber daya berdasarkan tujuan program dan hasil terukur (GAO, 1993). Robinson dan Brumby (2005) menjelaskan anggaran berbasis kinerja sebagai prosedur atau mekanisme yang dimaksudkan untuk memperkuat kaitan antara dana yang diberikan kepada entitas sektor publik dengan outcome dan/atau outcome mereka melalui penggunaan informasi kinerja formal dalam pengambilan keputusan alokasi sumber daya. Dimana anggaran tersebut berfokus pada aktivitas atau fungsi yang memproduksi hasil dan sumber daya yang digunakan serta memperkenalkan proses penganggaran yang berusaha untuk menghubungkan tujuan organisasi dengan sumber daya. Pada dasarnya tujuan utama anggaran berbasis kinerja ini adalah meningkatkar efisiensi dan efektivitas belanja publik dan GAO mendefinisikan anggran berbasis kinerja sebagai konsep yang mengkaitkan informasi kinerja dengan anggaran. 
Menurut Mardiasmo (2002) anggaran dengan pendekatan kinerja disusun untuk mengatasi berbagai kelemahan yang ada di anggaran tradisional, khususnya kelemahan yang disebabkan oleh tidak adanya tolak ukur yang dapat digunakan untuk mengukur kinerja dalam pencapaian tujuan dan sasaran pelayanan publik. Bagi Negara Indonesia sendiri, implementasi anggaran berbasis kinerja atau dalam Permendagri No.13 tahun 2006 disebut dengan anggaran pendekatan prestasi kerja merupakan pendekatan yang relatif baru diterapkan dalam sistem penganggaran di Indonesia.

\section{Konsep Reformasi Anggaran Berbasis \\ Kinerja}

Proses reformasi anggaran di Amerika Serikat timbul karena upaya dari gerakan progresif yang mengembangkan analisis sistematik terhadap aktivitas-aktivitas pemerintahan dan operasi pemerintahan. Analisis di masa lalu menunjukkan bahwa anggaran berbasis kinerja berhubungan dengan masalah-masalah yang secara institusional dari reformasi anggaran (Shick, 1971 dalam Willoughby dan Melkers, 2001). Sebagai contohnya, implementasinya meliputi masalahmasalah berikut ini:

a. Kepemimpinan dan komitmen terhadap organisasi.

b. Kontinuitas dalam fokus reformasi administrasi.

c. Sumber daya yang cukup dalam usaha mewujudkan reformasi (waktu, uang, personel).

d. Harapan yang berlebihan akan kesuksesan. Kegagalan reformasi anggaran sering disebabkan karena pemahaman yang tidak cukup oleh pelaksana anggaran dan syarat-syarat reformasi yang harus dipenuhi dalam proses penganggaran.

Howard (1973) menegaskan bahwa beberapa reformasi khususnya inisiatif untuk mengembangkan penganggaran yang lebih rasional bukan merupakan sebuah metode alokasi sumber daya, tetapi sebuah usaha untuk mendukung pembuatan keputusan. Sesuai dengan hal tersebut, kesuksesan dari reformasi anggararan tergantung pada penerimaan individual terhadap reformasi sama baiknya dengan kemauan mereka untuk merubah bagaimana mereka berpikir dan bertindak.

\section{Efektivitas Implementasi Anggaran \\ Berbasis Kinerja Dan Aspek Rasional}

Efektivitas implementasi anggaran

berbasis kinerja dilihat dari sudut pandang rasional merupakan isu teknis. Sistem pengukuran kinerja yang dilandasi oleh konsep value for money, dan anggaran yang berorientasi hasil menekankan pada suatu pemikiran logis/rasional dan teknis dalam mengelola suatu perubahan dalam suatu organisasi.

Asmadewa (2006) berpendapat bahwa tahap implementasi anggaran berbasis kinerja merupakan tahap penggunaan informasi kinerja dalam proses penganggaran untuk memberikan dampak yang sebenarnya pada efisiensi, efektivitas, dan pengambilan keputusan, dan akuntabilitas. Pencapaian efektivitas implementasi anggaran berbaisi kinerja dapat dilihat dari keterkaitan hasil program dengan target atau tujuan yang ditetapkan.

Dalam proses pengimplemetasian anggaran berbasis kinerja, sejumlah literatur dan penelitian mengindikasikan adanya sejumlah aspek yang berpengaruh bagi keberhasilan implementasi tersebut adalah aspek rasional (Julnes dan Holzer, 2001). Aspek rasional adalah aspek yang mendasarkan pada pemikiran logis/penalaran sebagai pertimbangan tertinggi untuk menentukan hal seperti pendapat, perbuatan, penilaian, dan sebagainya (Darmansjah, 2002). Penelitian Wang (2000) menemukan indikasi adanya hubungan antara pengembangan kapasitas pengukuran kinerja (melibatkan sumber daya dana, staf, dan sistem informasi) dengan penggunaan pengukuran kinerja dalam penganggaran.

\section{Penelitian Terdahulu}

Beberapa penelitian mengenai efektrivitas implementasi anggaran berbasis kinerja diantaranya adalah penelitian Crain dan O'Roack (2004) menemukan kehadiran anggaran berbasis kineja baru dapat menurunkan belanja total dari negara bagian setidaknya sebesar $1,3 \%$ dari pendapatan di negara bagian, dan $2 \%$ per kapita. Hasil temuan ini sejalan dengan hasil survei yang dilakukan oleh Willougby dan Melkers (2000) terhadap penganggar di 49 negara bagian, baik eksekutif maupun legislatif. Tanggapan para responden dalam survei tersebut belum mengindikasikan adanya kemajuan implementasi dalam mempengaruhi aprosiasi yang dapat dikaitkan langsung dengan outcome dalam implementasi anggaran berbasis kinerja.

Penelitian lain tentang anggaran berbasis kinerja yang mengindikasikan adanya kemajuan diantaranya dari survei yang sama dilakukan oleh Willougby dan Melkers (2001), menemukan bahwa secara keseluruhan implementasi anggaran berbasis kinerja telah memberikan dampak perbaikan pada efektivitas 
program lembaga dan pengambilan keputusan dalam pemerintah. Sementara Jordan dan Hackbart (1999) dalam penelitiannya atas status anggaran berbasis kinerja dan pendanaan kinerja, menemukan bahwa ketika anggaran berbasis kinerja diimplementasikan, maka pencapaian standar kinerja akan mempengaruhi rekomendasi dalam anggaran gubernur (eksekutif) dan kinerja dapat mempengaruhi pendanaan anggaran tahun berjalan setelah apropriasi awal.

Broom (1995) menyimpulkan bahwa pemberian informasi kinerja dalam proses penganggaran, walaupun tidak mentransformasi proses keputusan, namun memberikan nilai tambah pada pertimbangan. Konsisten dengan hal tersebut, Wang (2000) menemukan bahwa pengunaan pengukuran kinerja dalam penganggaran dipandang memiliki dampak positif pada kinerja organisasi. Penggunaan pengukuran kinerja dalam penganggaran disimpulkan dapat berdampak pada pemerintah, menentukan tujuan organisasi, memonitor praktik manajemen, dan dalam beberapa kasus membuat alokasi anggaran. Sedangkan penelitian Cavaluazzo dan Ittner (2004) menunjukkan pengukuran kinerja merupakan kepatuhan terhadap akuntabilitas laporan publik.

Terkait implementasi anggaran berbasis kinerja terhadap terciptanya pengambilan keputusan pada dasarnya mendukung untuk terciptanya pengambilan keputusan yang lebih rasional (secara rasional). Penelitian Goodman dan Clynch (2004) atas pengambilan keputusan anggaran oleh analis anggaran baik dari eksekutif maupun legislatif mendukung bukti dari penelitianpenelitian sebelumnya yang membenarkan kompleksitas faktor-faktor yang mempengaruhi keputusan analis anggaran. Sedangkan terkait dengan aspek rasional, penelitian yang dilakukan oleh Julnez dan Holzer (2001) tentang utilisasi kinerja pada organisasi publik yang melibatkan Kerangka Berfikir

Variabel Independen

Aspek Rasional dalam Penganggaran Publik

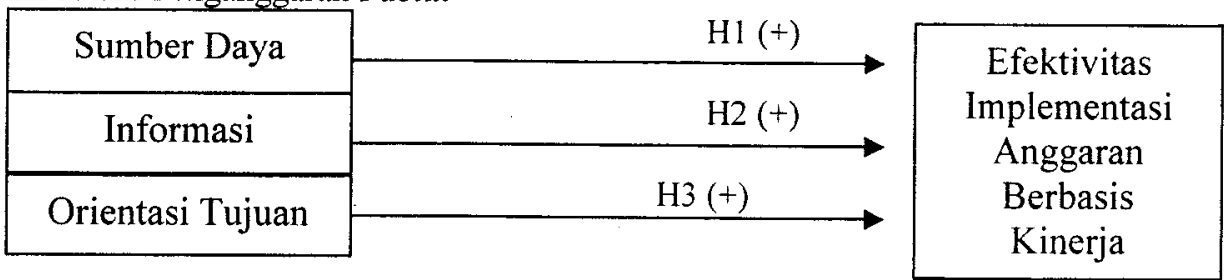

\section{METODE PENELITIAN}

1. Pengumpulan Data Dan Pemilihan Sampel

Data dalam penelitian adalah data primer yang diperoleh melalui metode survei dengan chacy adopsi dan implementasi, penelitian icrsebut menyimpulkan bahwa kebijakan adopsi dalam utilisasi ukuran kinerja dipengaruhi oleh aspek rasional yang meliputi faktor sumber daya, informasi, orientasi tujuan organisasi publik.

Di Indonesia, Asmadewa (2006) melakukan penelitian tentang faktor-faktor yang mempengaruhi efektivitas implementasi anggaran berbasis kinerja menunjukkan bahwa yang meneliti faktor sumber daya dan informasi terhadap implementasi anggaran berbasis kinerja pemerintah pusat. Hasil dari penelitian ini menunjukkan adanya pengaruh yang signifikan pada faktor sumber daya dan informasi terhadap implementasi anggaran berbasis kinerja di pemerintah pusat.

\section{Pengembangan Hipotesis}

Berdasarkan literatur dan penelitiannya sebelumnya, pada bagian ini penelitian akan menghubungkan aspek rasional terhadap efektivitas implementasi anggaran berbasis kinerja. Aspek-aspek rasional yang diduga mempengaruhi proses implementasi meliputi sumber daya, informasi dan orientasi tujuan. Oleh karena itu penelitian ini akan mengajukan proposisi bahwa aspek rasional mempengaruhi efektivitas implementasi anggaran berbasis kinerja.

$H l=$ variabel sumber daya berpengaruh positif terhadap efektivitas implementasi anggaran berbasis kinerja

$H 2=$ variabel informasi berpengaruh positif terhadap efektivitas implementasi anggaran berbasis kinerja

$H 3$ = variable orientasi tujuan berpengaruh positif terhadap efektivitas implementasi anggaran berbasis kinerja

\section{Variabel dependen}

menggunakan kuisioner. Populasi dalam pene!itian ini adalah Satuan Kerja Perangkat Daerah pemerintalı kota Surakarta. Dimana Satuan Kerja Perangkat Daerah merupakan 
perangkat daerah pada pemerintah daerah selaku pengguna anggaran. Sedangkan sampel yang digunakan adalah pejabat pengguna anggaran dimana pejabat pengguna anggaran merupakan pejabat yang mempunyai kewenangan penggunaan anggaran untuk melaksanakan tugas pokok dan fungsi Satuan Kerja Perangkat Daerah yang dipimpinya. Untuk pengambilan sampel ini, peneliti menggunakan metode purposive atau lebih tepatnya dengan judgement sampling untuk memilih anggota sampelnya (responden). Beberapa kriteria yang melandasi pemilihan responden adalah bahwa responden tersebut terlibat dalam perencanaan penyusunan anggaran, pengukuran kinerja dan dalam pengambilan keputusan anggaran serta yang nantinya mengembalikan kuisioner. Dalam Permendagri 13 tahun 2006 pasal 10 adalah pejabat pengguna anggaran adalah kepala Satuan Kerja Perangkat Daerah atau pejabat yang diberikan kewenangan atas penggunaan anggaran. Dimana Sesuai dengan Peraturan daerah no 6 tahun 2008 tentang organisasi dan tata kerja perangkat daerah kota Surakarta, satuan kerja perangkat daerah berjumlah 84 satuan kerja perangkat daerah sehingga nantinya kuisioner yang akan disebarkan sebanyak 84 yang ditujukan kepada pejabat pengguna anggaran pada tiap Satuan Kerja Perangkat Daerah.

\section{Pengukuran Variabel Dan Definisi Operasional}

Penelitian ini menggunakan 4 variabel yang terdiri dari 1 variabel dependen (efektivitas implementasi anggaran berbasis kinerja) dan 3 variabel independen (sumber daya, informasi, orientasi tujuan). Untuk kuisionernya sendiri diadopsi dari penelitian penelitian Willlougby dan Melkers (2001), penelitian Julnes dan Holzer (2001) dan penelitian Cavaluazzo dan Ittner (2003)

Scmua variabel dalam penelitian ini diukur dengan menggunakan skala likert dengan 4 skala poin, yakni 1 untuk skala terendah dan 4 untuk skala tertinggi sebagai pilihan tanggapan responden. Hal ini sesuai dengan penelitian yang terdahulu dan jawaban ragu-ragu (netral) dihilangkan dengan alasan kebanyakan subyek penelitian cenderung akan memilih jawaban yang netral (Hadi, 1994).

\section{Efektivitas implementasi anggaran berbasis kinerja}

Efektivitas implementasi anggaran berbasis kinerja adalah tahap penggunaan kinerja dalam proses penganggaran untuk memberikan dampak pada tingkat hasil program yang ditetapkan (Asmadewa, 2006). Sistem anggaran berbasis kinerja pada dasarnya merupakan sistem yang mencakup kegiatan penyusunan program dan tolak ukur kinerja sebagai instrumen untuk mencapai tujuan dan sasaran program (Mardiasmo, 2002).

\section{a. Sumber daya}

Sumber daya adalah komponen yang harus dimiliki perusahaan untuk mencapai tujuannya (Alimiv yal dan Padji, 2003). Sumber daya adalah aktor rasional yang mengukur sejauh inana organisasi memiliki sumber daya yang relevan untuk efektivitas implementasi anggaran berbasis kinerja (Asmadewa, 2006). Apabila terdapat sumber daya, yaitu staf dan dana dikhususkan untuk mengembangkan, mengumpulkan dan mengevaluasi kinerja maka akan berdampak pada pengadopsian suatu ukuran kinerja (Julnes dan Holzer, 2001). Staf yang capable dan tersedianya sumber daya keuangan sangat penting dalam mengembangkan dan memantau ukuran kinerja (Wang, 2002).

\section{b. Informasi}

Informasi adalah data yang telah disaring, dianalisis, ditata, dan disampaikan dalam bentuk yang berguna untuk mencapai tujuan-tujuan organisasi (Anthony et al. 1989). Informasi juga merupakan faktor rasional yang mencerminkan pengetahuan teknis (Asmadewa, 2006). Dalam implementasi pengukuran kinerja pegawai (manajemen) maupun pegawai (non manajemen) harus memiliki kemampuan teknis tentang bagaimana melakukan dan mengimplemtasikan pengukuran kinerja (Halim dan Sihaloho, 2005). Sehingga variabel ini menecrminkan data yang berguna yang dimiliki pegawai (manajemen) maupun pegawai (non manajemen) terkait akses terhadap peraturan, perundangan, literature yang terkait dengan pengukuran kinerja (Julnes dan Holzer, 2001).

\section{c. Orientasi Tujuan}

Orientasi tujuan adalah faktor rasional yang mengukur sejauh mana organisasi berorientasi kepada pencapaian tujuan (Asmadewa, 2006). Hal ini seperti apa yang diungkapkan Halim dan Sihaloho (2006), bahwa orientasi tujuan merupakan konsesus terhadap tujuan dari setiap program. Selain itu orientasi tujuan juga dikonseptulisasikan sebagai suatu mental framework bagaimana individu menginterpretasi dan merespon situasi/kejadian yang dihadapinya (Ames dan Archer, 1988).

\section{HASIL DAN PEMBAHASAN}

\section{Statistik Deskriptif}

Jumlah responden yang berhasil terkumpul hingga batas akhir pengujian kuisioner adalah 75 sampel yang berasal dari 84 kuisioner yang disebar pada Satuan Kerja Perangkat Daerah. Tingkat pengembalian kuisioner adalah $89 \%$ (75 dari 84 yang ditargetkan). Tetapi setelah di cek kembali ada 3 data sampel yang datanya tidak bisa diolah karena tanggapan atas kuisoner tidak lengkap, 
Tabel 1.

Karakteristik Sampel

\begin{tabular}{lll}
\hline Karakteristik & Mean & Kisaran \\
\hline $\begin{array}{l}\text { Usia (tahun) } \\
\text { Masa Kerja (tahun) }\end{array}$ & $\begin{array}{l}44 \text { tahun } \\
19 \text { tahun }\end{array}$ & $\begin{array}{l}30-54 \text { tahun } \\
3-30 \text { tahun }\end{array}$ \\
\hline Persentase dari sampel & Jumlah & $\%$ \\
\hline Kelamin & & \\
- Laki-laki & 49 orang & $68 \%$ \\
Pendidikan & 23 orang & $32 \%$ \\
- D3 & & \\
- S1 & 3 orang & $4 \%$ \\
S2 & 47 orang & $65 \%$ \\
\hline
\end{tabular}

Selanjutnya secara detail disajikan nilai mean, median serta deviasi standar dari masingmasing variabel. Untuk kisaran teoritis sendiri ditentukan dari kemungkinan responden memilih semua jawaban dengan nilai atau poin terkecil dari masing-masing item dan kemungkinan responden

memilih semua jawaban dengan nilai atau poin terbesar dari masing-masing item pertanyaan. Tetapi pada kenyataannya berdasarkan kisaran aktual dari jawaban responden ternyata cukup bervariasi dari jawaban yang mereka pilih.

Tabel 2.

Statistik Deskristif tiap variabel.

\begin{tabular}{|c|c|c|c|c|c|c|c|}
\hline $\begin{array}{c}\text { Variabel } \\
\vdots \\
\vdots\end{array}$ & & $\begin{array}{c}\text { Jumlah } \\
\text { item }\end{array}$ & Mean & Median & $\begin{array}{l}\text { Kisaran } \\
\text { Teoritis }\end{array}$ & $\begin{array}{c}\text { Kisaran } \\
\text { Aktual }\end{array}$ & $\begin{array}{l}\text { Deviasi } \\
\text { Standar }\end{array}$ \\
\hline Efektivitas Anggaran Berbasis & $\mathrm{Y}$ & 7 & 21,013 & 21 & $7-28$ & $13-26$ & 2,3406 \\
\hline Kinerja & $\mathrm{X}$ & 5 & 9 & 15 & $5-20$ & $9-20$ & 2,3721 \\
\hline Sumber Daya & 1 & 3 & 15,250 & 8 & $3-12$ & $5-11$ & 1,4502 \\
\hline Informasi & $\mathrm{X}$ & 4 & 0 & 12 & $4-16$ & $8-15$ & 1,7562 \\
\hline Orientasi Kinerja & 2 & & 7,7917 & & & & \\
\hline & $X$ & & 11,988 & & & & \\
\hline & 3 & & 1 & & & & \\
\hline
\end{tabular}

Sumber : hasil olah data

\section{Hasil Uji Validitas dan Realibilitas}

Hasil uji validitas dan realibilitas instrumen penelitian yang disebar pada sampel di Satuan Kerja Perangkat Daerah 'menunjukkan bahwa item pertanyaan (tabel 3) juga menunjukkan bahwa semua item pertanyaan berkorelasi dengan skor total konstruk secara signifikan. Jadi dapat disimpulkan bahwa tiap item pertanyaan tersebut adalah valid dan dapat digunakan untuk mengukur variabel-variabel dalam penelitian ini.

Tabel 3.

Hasil uji validitas dan reliabilitas

\begin{tabular}{lcrc}
\hline Variabei & & Kisaran Korelasi & Cronbach's Alpha \\
\hline Efektivitas Anggaran berbasis kinerja & $\mathrm{Y}$ & $0,581-0,674$ & 0,729 \\
Sumber Daya & $\mathrm{X}_{1}$ & $0,608-0,745$ & 0,695 \\
Informasi & $\mathrm{X}_{2}$ & $0,670-0,794$ & 0,694 \\
Orientasi Kinerja & $\mathrm{X}_{3}$ & $0,6 ! 6-0,816$ & 0,623 \\
\hline
\end{tabular}

Sumber : hasil olah data 
Sedangkan untuk hasil uji reliabilitas menunjukkan 'bahwa nilai cronbarh alpha untuk semua variabel lebih besar da; 0,6. Sehingga dapat disimpulkan bahwa kuisoner yang digunakan dalam penelitian ini adalah reliabel atau handal .

\section{Hasil Uji Asumsi Klasik}

Dari hasil uji normalitas menunjukkan bahwa besarnya nilainya Kolmogorov-Smirnov adalah 0,609 dan signifikansinya adalah 0,852 Sehingga karena nilai signifikansinya lebih dari 0,05 maka dapat dikatakan bahwa data tersebut berdistribusi normal.

Sedangkan terkait hasil analisis menunjukkan bahwa nilai VIF semua variabel independen di bawah nilai 10 dan Tolerance value diatas 0,10 . Sehingga dapat disimpulkan dari hasil diatas maka tidak ada multikolinearitas antar variabel independen dalam model regresi.

Untuk uji heteroskedastisitus dalam! penelitian ini dilakukan uji Glejser. Lhmana dalam uji ini meregresi nilai absolut residual terhadap varibel independen. Dari hasil olah data yang dilakukan menunjukkan bahwa tidak ada satupun variabel yang secara signifikan secara statistik mempengaruhi variabel dependen nilai absolut. Hai tersebut terlihat dari probabilitas signifikansinya di atas tingkat kepercayaan 5\%. Jadi dapat disimpulkan model regresi tidak mengandung adanya Heteroskedastisitas.

\section{Pengujian Hipotesis}

Dari hasil perhitungan dari data yang diperoleh secara studi empiris disajikan dalam tabel 4 sebagai berikut :

Tabel 4.

Hasil analisis regresi implementasi anggaran berbasis kinerja pada faktor rasional

\begin{tabular}{|c|c|c|c|c|c|}
\hline \multirow[b]{2}{*}{ Model } & \multicolumn{2}{|c|}{$\begin{array}{c}\text { Unstandardized } \\
\text { Coefficients }\end{array}$} & $\begin{array}{l}\text { Standardized } \\
\text { Coefficients }\end{array}$ & \multirow[t]{2}{*}{$\mathrm{t}$} & \multirow[t]{2}{*}{ Sig. } \\
\hline & $\mathrm{B}$ & Std. Error & Beta & & \\
\hline (Constant) & 13.985 & 1.945 & & 7.190 & .000 \\
\hline SD & .390 & .118 & .396 & 3.300 & $.002^{*}$ \\
\hline INFO & .484 & .197 & .300 & 2.464 & $.016^{* *}$ \\
\hline OT & -.227 & .162 & -.171 & -1.406 & .164 \\
\hline R-squared & & & .274 & & \\
\hline Adjusted $\mathrm{R}^{2}$ & & & .242 & & \\
\hline$F$ & & & 8.576 & & \\
\hline
\end{tabular}

Sumber : hasil olah data

Berdasarkan hasil pengolahan data pada tabel 12 maka dapat dibentuk persamaan regresi sebagai berikut :

$\mathrm{Y}=13.985+0.390 \mathrm{X} 1+0.484 \mathrm{X} 2-0.227$ $\mathrm{X} 3$

Dari hasil olah data dapat diketahui bahwa aspek rasional mempengaruhi efektivitas implementasi anggaran berbasis kinerja sebesar $24.2 \%$, sedangkan sisanya dipengaruhi aspek yang lain. Dari hasil olah data tersebut diketahui bahwa sumber daya dan informasi berpengaruh signifikan secara positif terhadap efektivitas pengimplementasian anggaran berbasis kinerja pada tingkat signifikansi $1 \%\left(^{*}\right)$ dan $5 \%\left({ }^{* *}\right)$. Sedangkan untuk orientasi tujuan secara statistik tidak berpengaruh terhadap efektivitas pengimplementasian anggaran berbasis kinerja.

\section{Pembahasan}

Dalam konteks perkembangan implementasian anggaran berbasis kinerja yang digambarkan oleh para responden harus dimaknai dengan sangat hati-hati karena persepsi atas efektivitas anggaran berbasis kinerja yang digambarkan oleh para responden harus dipahami dalam konteks perkembangan awal pengimplemetasian. Pembahasan responden seperti yang diuraikan pada bagian sebelumnya memberikan indikasi yang kuat adanya perkembangan positif baik pada efektivitas anggaran berbasis kinerja dan pada aspek rasional.

Hasil analisis regresi menunjukkan bahwa aspek sumber daya berpengaruh secara positif terhadap efektivitas implementasi anggaran berbasis kinerja pada pemerintah kota Surakarta. Hal ini berarti hipotesis pertama yang peneliti ajukan diterima. Temuan ini konsisten dengan penelitian Julnez dan Holzer (2001), yaitu sumber daya terbukti mempengaruhi tahap implementasi dalam pemanfaaatan indikator 
kinerja serta penelitian Asmadewa (2007) dimana menunjukkan adanya pengaruh yang signifikan pada faktor sumber dayi terhadap implementasi anggaran berbasis kineria di pemerintah pusat.

Dukungan sumber daya dalam setiap regulasi pada organisasi pemerintah pada umumnya merupakan hal yang formal yang harus dilakukan dan upaya tersebut terhadap telah coba dilakukan oleh organisasi pemerintan (satuan kerja perangkat daerah) di Surakarta. Alokasi dana dan penetapan pegawai untuk melaksakan peraturan baru, serta waktu yang disediakan lebih merupakan hal yang harus dilakukan sebagai bentuk respon birokrasi dan bentuk disiplin untuk menunjukkan bahwa organisasi telah melaksanakan hal yang tepat.

Hipotesa kedua yang peneliti ajukan dalam penelitian ini juga diterima. Hal ini dikarenakan dari hasil analisis data menunjukkan bahwa variabel informasi yang berpengaruh secara signifikan terhadap efektivitas implementasi anggaran berbasis kinerja. Pengaruh informasi yang signifikan mempengaruhi efektivitas impiementasi anggaran berbasis kinerja, diperkuat dengan para persepsi responden. Hal ini dikarenakan sebagian besar responden mengindikasikan sudah ada upaya untuk mengikuti pelatihan atau workshop atau seminar tentang anggaran berbasis kinerja khususnya bagi pegawainya

Sedangkan hipotesa ketiga yang peneliti ajıkan dalam penelitian in ditolak. Tidak ada nya pengaruh yang signifikan variabel orientasi tujuan terhadap efektivitas implementasi anggaran berbasis kinerja pada pemerintah kota Surakarta menurut peneliti karena para penganggar tidak memiliki orientasi tujuan dan orientasi efisiensi terkait dengan anggaran berbasis kinerja. Orientasi menghabiskan anggaran tanpa memperhatikan kualitas output dan tujuan program yang telah disusun dalam perencanaan strategis pelaksanaan anggaran merupakan paradigma anggaran tradisional. Dimana paradigma tersebut bertolak belakang dengan anggaran berbasis kinerja yang memperhatikan ke erkaitan dana publik dengan output dan tujuan program. Hal-hal ini terjadi karena kompetensi pejabat pengguna anggaran dalam hal pemahaman anggaran berbasis kinerja masih belum optimal.

Keberhasilan efektivitas implementasi anggaran berbasis kinerja sangat ditentukan dengan pengukuran kinerja yang ada, karena pengukuran kinerja yang digunakan dalam penyususnan anggaran sangat mengandalkan keakuratan informasi dari sistem tersebut dan pengukuran kinerja merupakan suatu bentuk kepatuhan terhadap akuntabilitas laporan publik. Dari hasil analisis juga menunjukkan bahwa pengukuran kinerja yang tepat dan akurat menjadi dasar penyusunan anggaran telah berusaha dilakukan sebagai upaya efektivitas implementasi anggaran berbasis kinerja.

Berdasar analisa data mengindikasikan bahwa perkembangan efektivitas implementasi anggaran berbasis kinerja pada pemerintah kota Surakarta saat ini belum sepenuhnya menyentuh seluruh aspek rasional. Efektivitas implementasi anggaran berbasis kinerja lebih dijelaskan oleh dukungan sumber daya dan informasi dibanding perkembangan pada orientasi tujuan.

Terkait aspek-aspek rasional yang belum cukup menjelaskan kemajuan implementasi anggaran berbasis kinerja peneliti berpendapat bahwa hal ini mungkin disebabkan oleh sampel yang didapatkan belum sepenuhnya mewakili kondisi saat ini dan perkembangan pengimplementasian baru memasuki tahap awal. Penulis menyimpulkan untuk mencapai tingkat yang efektif masih diperlukan waktu yang cukup panjang dan banyak perbaikan pada aspek rasional sehingga nantinya mampu mempengaruhi pengambilan keputusan anggaran yang pada gilirannya dapat mempengaruhi efektivitas anggaran berbasis kinerja.

\section{PENUTUP}

Kesimpulan

Berdasarkan uraian pembahasan pada bab sebelumnya, maka dapat ditarik sejumlah kesimpulan sebagai berikut:

1. Variabel sumber daya dan informasi terbukti mempengaruhi secara positif efektivitas anggaran berbasis kinerja pada pemerintah kota Surakarta. Temuan ini konsisten dengan penelitian Julnez dan Holzer (2001), yaitu sumber daya terbukti mempengaruhi tahap implementasi dalam pemanfaaatan indikator kinerja serta penelitian Asmadewa (2007) dimana menunjukkan adanya pengaruh yang signifikan pada faktor sumber daya terhadap implementasi anggaran berbasis kinerja di pemerintah pusat. Konsisten pula 
dengan hasil penelitian Cavaluazzo dan Ittner (2003) yang memberikan bukti yang kuat dalam hal penggunaan informasi kinerja, bahwa tingkat pengembangan ukuran kinerja berhubungan secara positif dengan penggunanaan informasi kinerja yang berorientasi pada hasil. Khusus untuk orientasi tujuan, variabel ini tidak mempunyai pengaruh pada efektivitas anggaran berbasis kinerja pada pemerintah kota Surakarta.

2. Adanya pengaruh sumber daya dan informasi tidak berarti bahwa pengimplementasian anggaran telah berhasil merubah pendekatan anggaran menjadi lebih rasional, karena terbukti variabel orientasi tujuan belum mempunyai pengaruh terhadap efektivitas implementasi anggaran berbasis kinerja. Hal ini mengindikasikan bahwa perkembangan pengimplementasian anggaran berbasis kinerja belum sepenuhnya mempertimbangkan kinerja dalam pengambilan keputusan anggaran serta dari sudut pandang teori organisasi yang melihat implementasi anggaran berbasis kinerja sebagai sebuah perubahan organisasional, perkembangan saat ini belum sepenuhnya efektif karena ada beberapa variabel yang belum memberikan pengaruh yang signifikan.

\section{KETERBATASAN}

Keterbatasan dalam penelitian ini adalah:

1. Penelitian ini memiliki keterbatasan yang dialami penelitian persepsian pada umumnya, yaitu masalah subjekstivitas responden. Keterbatasan ini membuat penelitian rentan terhadap biasnya jawaban responden. Untuk itu temuan dalam penelitian ini harus dimaknai dengan hati-hati.

2. Berdasarkan pengalaman penulis dalam survey ini, banyak sekali informasiinformasi yang terkait dengan pengimplementasian anggaran berbasis kinerja Pemerintah Kota Surakarta yang tidak ditangkap dalam kuisioner penelitian. Misalkan koordinasi antara bagian perencanaan dengan DPRD dalam rapat pembahasan anggaran menunjukkan pengalaman yang berbedabeda untuk tiap instansi/kantor atau bagaimana komitmen sebenarnya dari pimpinan instansi terhadap implementasi anggaran berbasis kinerja.
3. Mengingat objek penelitian ini hanya dilakukan pada lingkup Pemerintah Kota Surakarta dan belum mencakup kabupaten lain khususnya untuk Propinsi Jawa Tengah, jadi penelitian ini belum dapat digeneralisir secara luas.

\section{SARAN}

Saran untuk penelitian berikutnya adalah:

1. Penelitian ini hanya mencakup persepsi pejabat pengguna anggaran atau pejabat yang diberikan kekuasaan oleh pejabat pengguna anggaran yang memahami anggaran berbasis kinerja. Untuk penelitian selanjutnya, penelitian dapat diperluas dengan melibatkan Biro Perencanaan, Biro Keuangan, Biro program termasuk program dan unit organisasi yang meliputinya. Sehingga data yang didapatkan dari satuan-satuan kerja tersebut dapat menggambarkan dinamika yang sebenarnya terjadi.

2. Penelitian selanjutnya juga dapat memasukkan aspek budaya atau politis seperti dukungan inernal, dukungan eksternal, sikap keterbukaan organisasi pada perubahan (Julnez dan Holzer, 2001) untuk melihat perbedaan pengaruh aspek rasional dan aspek politis serta budaya dalam pengimplemetasian anggaran berbasis kinerja.

3. Dalam penelitian anggaran berbasis kinerja pada pemerintah kota-kabupaten yang lain dapat dilakukan dengan data sekunder untuk membuktikan keefektifan implementasi dan melengkapi hasil temuan penelitian persepsian ini.

DAFTAR PUSTAKA

Ames, C. dan J. Archer. 1988. Achievement Goals in the Classroom: Students' Learning Strategies and Motivation Processes. Journal of Educational Psychology, Vol 80: 260-267.

Antony, R. N., J. Dearden dan N. M. Bredford. $1992 . \quad$ Sistem Pengendalian Manajemen. Jakarta. Binarupa Aksara.

Asmadewa, I. 2006. Faktor-Faktor Yang Mempengaruhi Keefektifan Implementasi Anggaran Berbasis Kinerja (Survei pada Pemerintah Pusat). Thesis UGM. Unpublished.

Bastian, I. 2006. Akuntansi Sektor Publik: Suatu Pengantar. Jakarta. Penerbit Erlangga.

Broom, C. A. 1995. Performance-Based Government Models: Building a 
Tracks Record. Public Budgeting and Finance, Vol 15 (4): 3-17.

Covaluazzo ,K S. and Ittner, C. D. 2003. Implementing performance measurement innovations evidence from government Accounting Organization and Society,April/may, Vol 29: 243268.

Crain, W. M. dan J. B. O'Roack. 2004. The impact of performance-based budgeting on state fiscal performance. Economics of governance, Vol 15: 168-186.

Darmansjah, I. 2002. Strategic Plannings. Available at: http://www iwandarmansjah.web.id

Departemen Dalam Negeri. 2006. Peraturan Menteri Dalam Negeri No. 13 tahun 2006 tentang Pedoman Pengelolaan Keuangan Daerah. www.depdagri.go.id.

General Accounting Office. 1993. Performance Budgeting, State Experience and Implications for the Federal Government. GAO/AFMD93-41. Washington D.C.

General Accounting Office. 2005. Performance Budgeting: Efforts to Restructures Budget to Better Align Resources with Performance. GAO05-117. Washington D.C.

Ghozali, I. 2001. Aplikasi Analisis Multivariate dengan program SPSS. Semarang. Bagian Penerbit UNDIP.

Goodman , D. dan E. J. Clynch. 2004. Budgetery decision making by eksekutif and legislative budget analysts: The impact of politicial Cues and Analytical Information. Public Budgetering \& Finance, Fall: 20-37.

Hadi, S. 1994. Metode Reseach I. Andy Offset, Yogyakarta.

Halim, A. dan F.L.Sihaloho. 2005. Pengaruh faktor-faktor rasional, politik dan kultur organisasi terhadap pemanfaatan informasi kinerja instansi pemerintah daerah. SNA VII: 774-790.

Hood, C. 1991. A Public Management for All Seasons?, Public Administration, Vol. 61 (Spring): 143-149.

Howard, S. K. 1973. Changing State Budgeting. Lexington KY: Council of State Goverments.
Jordan, M. M. dan M. Harkbart. 2005. The Goal and Implementing Succes of state Performanos-based Budgeting, Jourval of Puble Budgeting, Accounitng ana Financial Management. Vol. 17 (4): 471-489.

Joyce, P. G. 1993. Using Performance measures for federal budgeting : Proposals and prospects. Public budgeting finance, Vol. 13(4): 3-17.

Julnes, P. deL. and M. Holzer. 2001. Promoting the Utilization of Performance Measures in Public Organizations, An Empirical Study of Faktor Affecting Adaptation and Implementation, Public Administration Review, Vol 61(6): 693-701.

Mardiasmo. 2002. Akuntansi Sektor Publik. Andi Yogyakarta.

Osborne, D. dan T. Gaebler. 1993. Reinventing Government, How the Entrepreneurial Spirit is Transforming the Public Sector. Reading Mass: Addison-Wesley.

Peraturan Daerah Kota Surakarta No. 6 Tahun 2008 tentang Organisasi dan Tata Kerja Perangkat Daerah Kota Surakarta, www.hukumdanham.surakarta.go.i d.

Robinson, M. dan J. Brumby. 2005. Does Performance Budgeting Work? An Analytical Review of the empirical literatur, IMF Working Paper $\mathrm{WP} / 05 / 210$.

Rubin, I. 1997. The politics of Public Budgeting: Getting ang Spending, Borrowing and Balancing. Chatham, NJ: Chatham House Publishers.

Wahyono, T. 2004. Cara Mudah Melakukan Analisa Statistik Dengan SPSS. Gava Media.

Wang, X. 2000. Performance Measurement in Budgeting: A Study in Country government. Public Budgeting and Finance. Vol 20(3): 105-120.

Willoughby, K. G. dan J. E. Melkers. 2000. Implementing PBB (Performance Based Budgeting) : Confilcting Views of Succes. Public Budgeting and Finance. Vol 20. 105-120. 2001. Budgeter's Views of State Performance Based Budgeting Systems. Public Administrations Review Vol 61(1) 54-64. 